\title{
Morphogenesis of the Sarine canyon in the Plateau Molasse, Switzerland: new data from an archaeological site
}

\section{Luc Braillard, Michel Mauvilly, Fribourg}

\section{Introduction}

From its source in the Helvetic nappes (Canton of Valais, Switzerland), the Sarine River stretches over 126 kilometres, passing through the Prealps (Cantons of Bern, Vaud and Fribourg) and ending in the Plateau Molasse at its confluence with the Aare River, about 20 kilometres west of the City of Bern. In its lower stretch, more precisely between the two artificial lakes of Gruyère and Schiffenen (S respectively $\mathrm{N}$ of Fribourg), the meandering course of the river is well developed, embedded in a 50 to 100 metre deep canyon in the Miocene Molasse bedrock (Fig. 1 and 2). This geomorphological feature, which bestows upon the medieval town of Fribourg most of its particular charm, is generally attributed to postglacial erosion. Thus, erosion is said to have carved epigenetic meandering gorges on the relatively smooth surface left bare by the retreat of the Rhône and Sarine glaciers (e.g. VAN der Meer 1982; Weidmann 2005). Indeed, fossil river courses have been identified in the area southwest of Fribourg either from geophysical excavations (e.g. Marescot et al.2003) or based on the evidence of natural outcrops along the present-day Sarine course (BüCHI 1926; DoRTHe 1962). The formation and fillings of these fossil channels still lack precise dating but are attributed to the Riss/Würm period or to older Interglacials (for more details, see FASEL 2005 or WEIDMANN 2005).

The recent discovery of an archaeological site, located at the bottom of the gorges and attributed to the Mesolithic period (Early Holocene), led to a reconsideration of the morphogenesis of the Sarine canyon. Indeed, this relatively old human occupation is a unique chronological marker that allows a more differentiated estimate of the erosion rates of the Sarine River since the Late Glacial period. The aim of this article is to present these new archaeological findings and to discuss their implications in light of the interrelationship between humans, environment and climate.

\section{The archaeological site of Arconciel/La Souche}

Discovered in 1998, the archaeological site of Arconciel/La Souche is situated about six kilometres upstream of the town of Fribourg. Set in the Sarine gorges, it consists of a southwest-facing rockshelter cut out of the Molasse by the Sarine River (Fig. 3), and lying five metres higher than the actual river bed (Fig. 4). Thanks to a 15 metre long and 5 metre deep overhang, the rockshelter offers a good refuge from bad weather as well as ideal habitat conditions (Fig. 5). Investigation of the shelter revealed that human occupation had occurred as far back as the Mesolithic period (MaUviLLY et al. 2004).

Rescue excavations began in 2003 as part of collaboration between the Universities of Bern, Neuchâtel and Fribourg. The site has since shown great potential for furthering the understanding of the development of human communities in this area between the $9^{\text {th }}$ and the $7^{\text {th }}$ millennia cal. BP. Due to the general lack of well-stratified sites dating to the end of the Mesolithic, excavations at the Arconciel/La Souche rockshelter offer valuable new data pertaining to local Neolithisation. For example, the discovery of a decorated clay seal dating back to 8000 years cal. BP (Fig. 6a) (MAUvILLY et al.) supports discussions on possible interaction between Western European Mesolithic cultures and early Neolithic societies from Southeast Europe. Until now, the three metre thick layers of this late Mesolithic rockshelter have revealed one of the most abundant series for the late Mesolithic in Switzerland; more than 50000 animal remains, 10000 artefacts made of siliceous rocks (radiolarites, quartzites, flints) which include tools (e.g. scrapers, arrowheads, wedges) and several bone tools and jewels made from perforated deer teeth have already been discovered (Fig. 6b, $c, d)$.

Data gathered during the first four excavation campaigns, each one lasting a month, allow the formulation of initial theories regarding the habitation dynamics of the shelter. A radiocarbon dating of the lowest hearth found in the stratigraphic units revealed human occupation as early as 8600 years ago (Fig. 7). However, during the first three quarters of the $9^{\text {th }}$ millennium cal. BP, the repetitive flood cycle of the Sarine River restricted inhabitation of the site. It is only around 8200 years cal. BP that the floods ceased - or at least decreased sufficiently - allowing Mesolithic huntergatherers to settle in the shelter. These dwellings left behind various sedimentary layers up to 50 centimetres thick that are archaeologically extremely rich. Between 7800 and 7000 years cal. BP approximately, the shelter was still inhabited, but far less frequently. This may be due to the collapse of part of the cliff. 


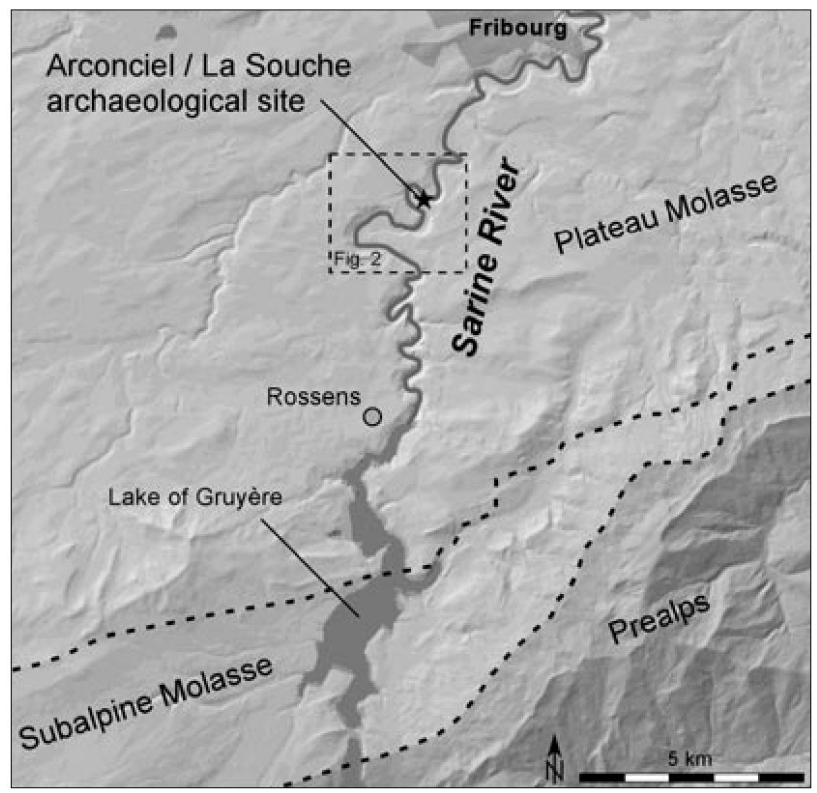

Fig. 1: Geographical and tectonical situation Situation géographique et tectonique Geographische und tektonische Lage

Base map: Atlas of Switzerland 2004, reproduced with permission of swisstopo (BA081240)

\section{Implications of this new archaeological data for the morphogenesis of the Sarine canyon}

The location of the archaeological site of Arconciel/La Souche, set at the bottom of the gorge five metres above the actual river, implies that most of the canyon was already dug at least 8600 years ago. Considering the age of the canyon (postglacial) and its mean depth in this portion of the river course $(\sim 100 \mathrm{~m})$, it appears that two different erosion rates were responsible for the formation of the Sarine canyon rather than a single long-term average event. Indeed, about 95 metres of sediments and Molasse were eroded between the end of the last glaciation and the Mesolithic occupation, and only five metres of Molasse has since been eroded. Taking into account the age of the fluvioglacial deposits that can be found high in the topography on both sides of the canyon (WEIDMANN et al. 2002), it is further possible to estimate these two erosion rates. These deposits are attributed by VAN DeR MeER (1982) to the first part of the Würmian Late Glacial (Oldest Dryas, about 19000 to 15000 years cal. BP); however, more precise dating is still lacking. Thus, it seems that erosion rate during Late Glacial to early Holocene times ( 0.9 to $1.48 \mathrm{~cm} /$ year) were dramatically high, dropping noticeably since the Atlantic period $(0.06 \mathrm{~cm} /$ year) (Fig. 8). These findings question the generally accepted explanation of constant erosion by the Sarine River since the Late Glacial. In the latter case, the fluvial erosion rate would have been between 0.53 to $0.67 \mathrm{~cm} /$ year ( $100 \mathrm{~m}$ of Molasse and Quaternary deposits eroded during $17000 \pm 2000$ years).

\section{Discussion and perspectives}

The proposed scenario for the morphogenesis of the canyon, that is a first phase of rapid incision followed by stabilisation and continued slower incision, is supported by a pedostratigraphic study conducted by VAN DER MEER (1982) on two fluvial terraces north of Fribourg. The soils of both terraces, located at the foot of the gorge, lie 15 metres, respectively 10 metres, above the actual valley bottom. The luvisols are well developed, and completely different from the soil on the valley floor. Based on the content of illuviated clay present in the B-horizon, and taking a former study by VAN DER Meer (1976) into account, an Older Dryas age was assigned to the high terrace and a Younger Dryas age to the low terrace. The consequence is that

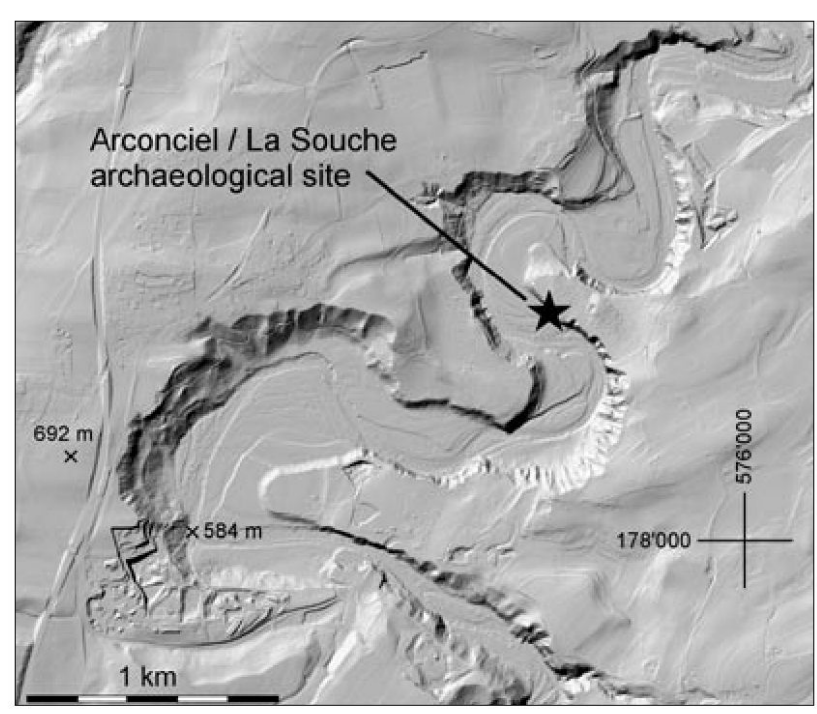

Fig. 2: Detailed topography of the incised meanders of the Sarine River between Rossens and Fribourg with position of the archaeological site of Arconciel/La Souche at the bottom of the canyon

Topographie détaillée des méandres encaissés de la Sarine entre Rossens et Fribourg, avec position du site archéologique d'Arconciel/La Souche au fond du canyon

Detaillierte Topographie der tief eingeschnittenen Mäander der Saane zwischen Rossens und Fribourg und die Lage der archäologischen Fundstätte von Arconciel/La Souche am Grund der Schlucht

Base map: Digital Height Model DOM, reproduced with permission of swisstopo (BA081240) 


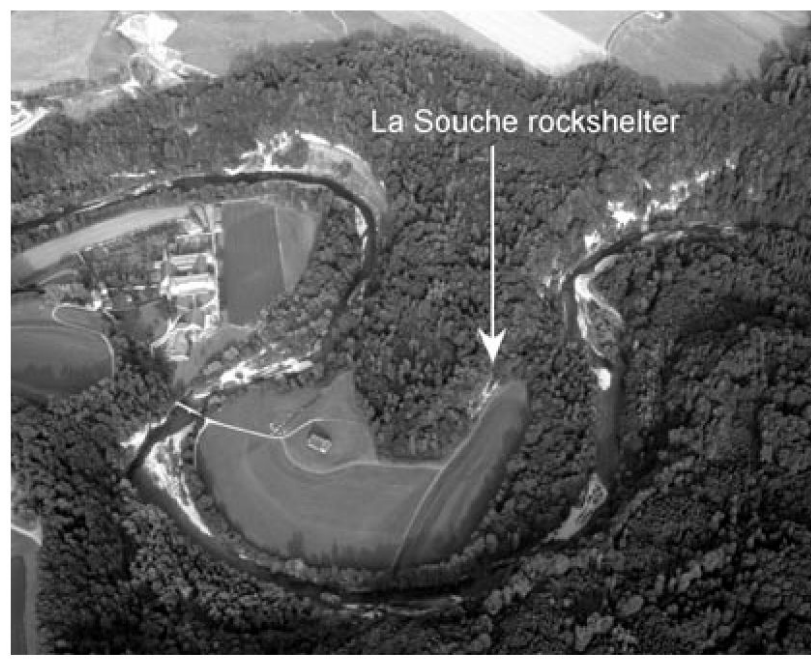

Fig. 3: Aerial view of the Arconciel/La Souche rockshelter

Vue aérienne de l'abri sous roche d'Arconciel/La Souche

Luftbild des Felsunterstands von Arconciel/La Souche Photo: L. BRaILlaRD

most of the canyon must have formed during the first part of the Late Glacial.

For the present study, the Sarine canyon is assumed to be a postglacial feature, an aspect which appears generally accepted. Therefore, except for the small portion of the river that cuts a former fossil course filled with loose material, the Sarine had to erode into the Molasse bedrock in order to form the canyon. Concerning this point, it should however be mentioned that VAN Der Meer (1976) does suggest the possibility of a pre-Würmian canyon that was filled with glacial or fluvioglacial sediments during the Würm, and postglacially re-excavated. Following this hypothesis, the nature of the material to be eroded would have facilitated the (re)formation of the canyon, but the rates of erosion deduced above remain unchanged.

The comparison of these archaeological and geological data offers exciting perspectives for Quaternary research. Firstly, archaeological excavation in the canyon should be intensified. Secondly, sediments that are cut by the canyon (tills, fluvioglacial and glaciolacustrine deposits) or that postdate its formation (calcareous tufa) should be dated (OSL, ${ }^{14} \mathrm{C}, \mathrm{U} / \mathrm{Th}$ ) in order to improve the chronostratigraphic framework. Thirdly, the pedostratigraphic study of terraces located at the bottom of the gorges, started by VAN DER MEER (1982) north of Fribourg, should be resumed and extended to other terraces sited in similar geomorphologic positions. If the strong erosion following the retreat of the glaciers is confirmed, a discussion of possible controlling factors could be of interest, such as the influence of 1) isostatic rebound of the lithosphere and subsequent uplift after deglaciation, 2) influence of the recently dated ( 18000 to 9000 years cal. BP) palaeolake of Gruyère situated upstream (BLUMER \& BRAILLARD 2004; PUGIN 1989), 3) role of grain size and sediment supply, 4) role of vegetation, 5) possibility of the presence of lines of weakness due to strong fracturing of the bedrock, and 6) Late Glacial climatic instability.

\section{References}

Blumer, R. \& L. Braillard (2004): La Tour-de-Trême/ Les Partsis: une nouvelle séquence mésolithique en Suisse romande. - In: Cahiers d'archéologie fribourgeoise 6: 66-81.

BüchI, O. (1926): Das Flussnetz der Saane und ihrer Nebenflüsse während den Interglacialzeiten (ausgenommen die Sense). - In: Bulletin de la Société fribourgeoise des Sciences naturelles 28: 128-148.

Dorthe, J.-P. (1962): Géologie de la région au sudouest de Fribourg. - In: Eclogae geologicae Helveticae 55, 2: 327-406.

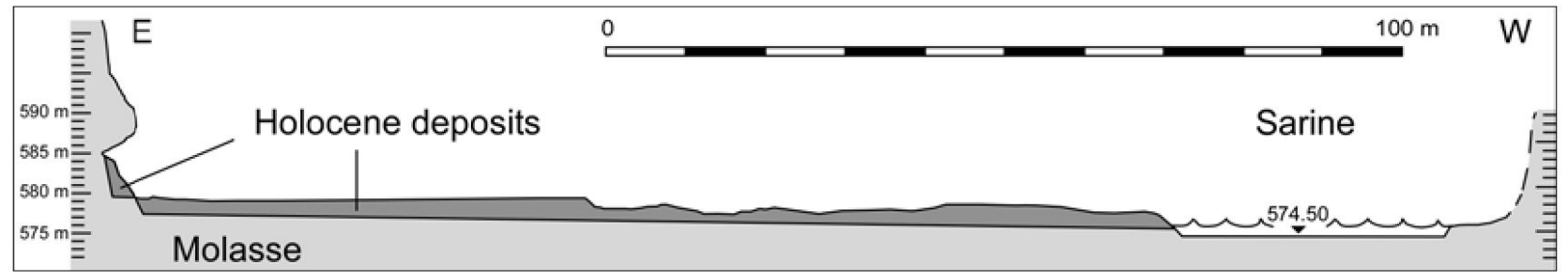

Fig. 4: Simplified cross section from the La Souche rockshelter (E) to the Sarine River (W) Coupe simplifiée depuis l'abri sous roche de La Souche (E) jusqu'à la Sarine (W)

Vereinfachter Querschnitt vom Felsunterstand bei Arconciel/La Souche (E) bis zur Saane (W)

Graphics: M. MaUviLLY 


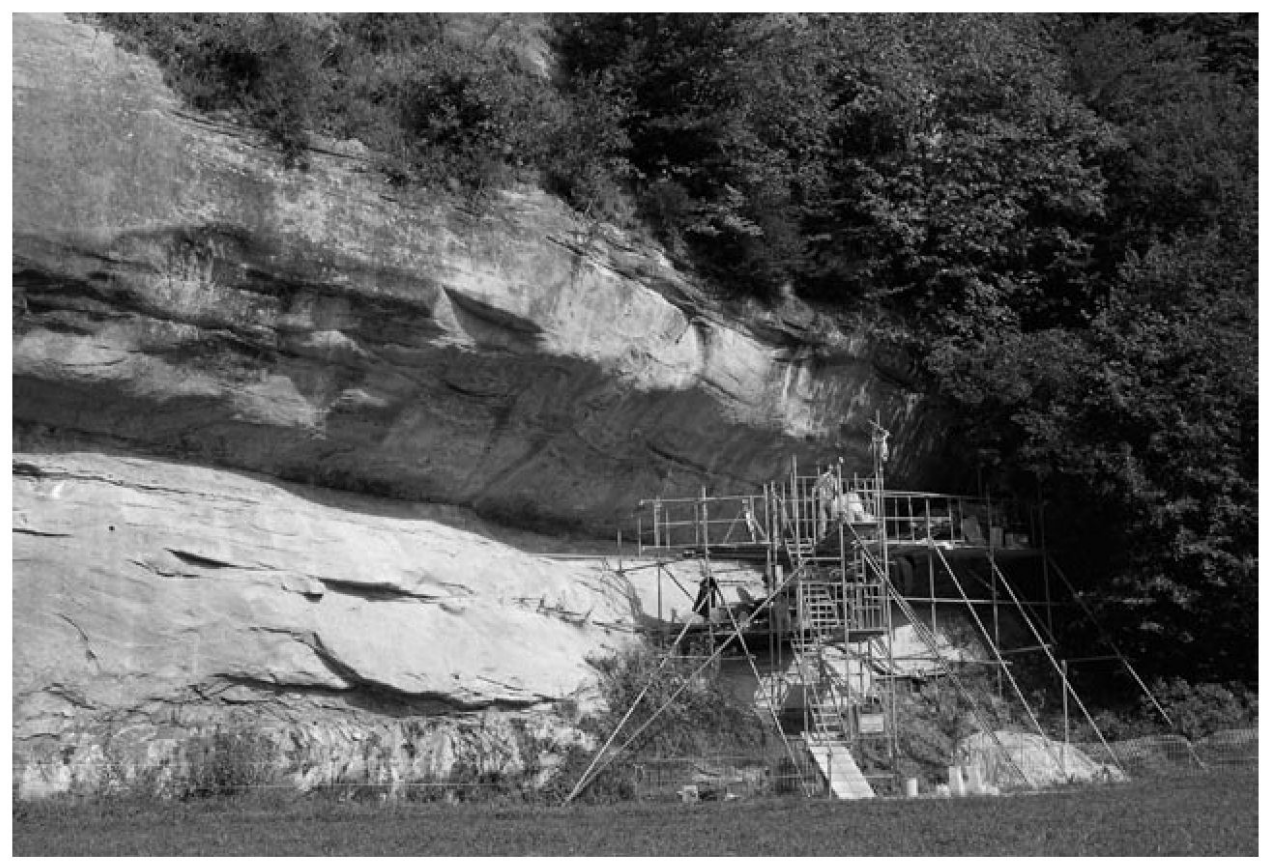

Fig. 5: Detailed view of the Arconciel/La Souche rockshelter during field work in 2004

Vue détaillée de l'abri sous roche d'Arconciel/La Souche lors de la campagne de fouilles de 2004

Detaillierte Ansicht von Arconciel/La Souche während der Ausgrabungen von 2004

Photo: L. BRAILLARD
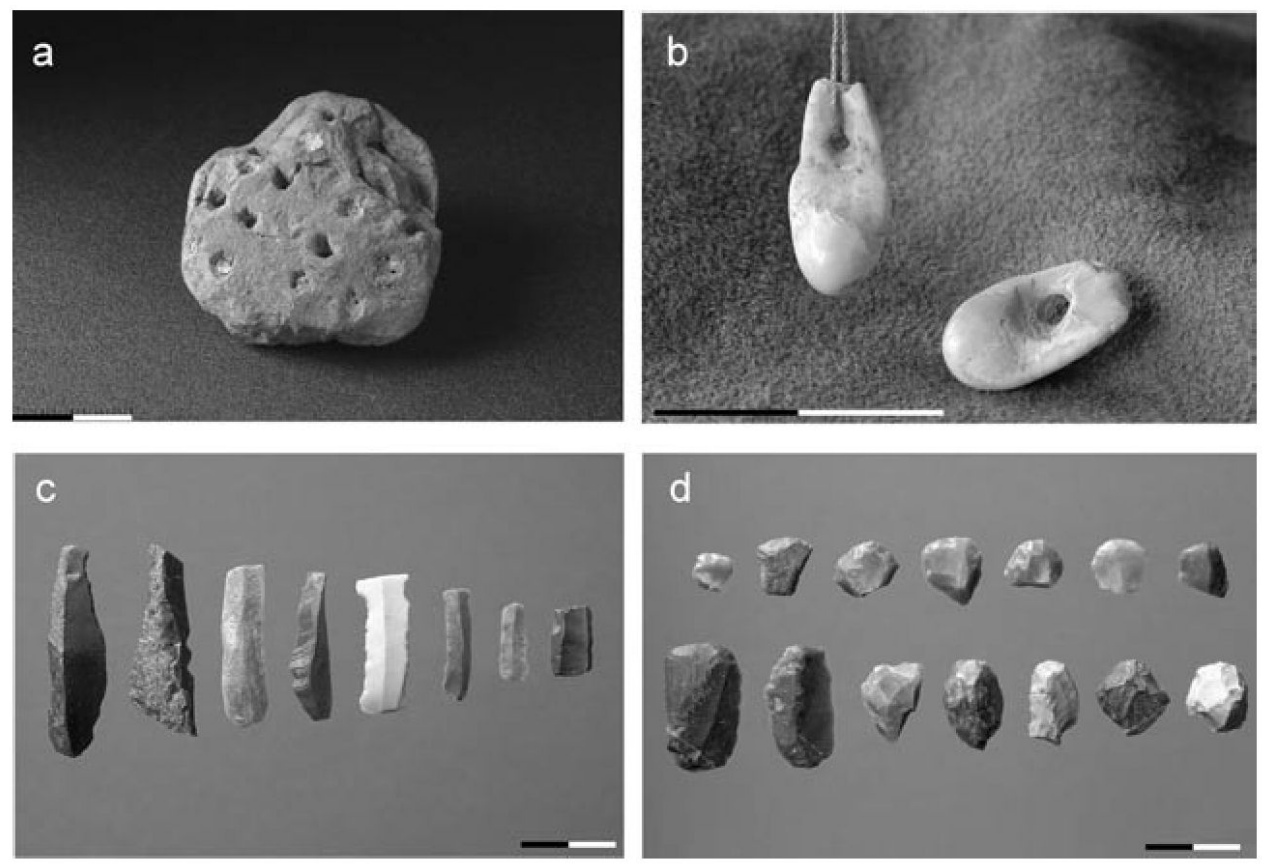

Fig. 6: Late Mesolithic artefacts: a) pintadera, representing the first known fired clay artefact of western Europe, b) perforated deer teeth, c) bladelets, d) scrapers (scale bars: $2 \mathrm{~cm}$ )

Artefacts du Mésolithique final: a) pintadera, représentant le plus ancien objet en terre cuite connu à ce jour en Europe de l'Ouest, $b$ ) dents de cerf perforées, c) lamelles, d) grattoirs (échelle: $2 \mathrm{~cm}$ )

Artefakte des Spätmesolithikums: a) Pintadera, der bis heute älteste Terrakotta-Gegenstand Westeuropas, b) Hirschzahnanhänger, c) Lamellen, d) Kratzer (Massstab: $2 \mathrm{~cm}$ )

Photo: Archaeological Survey, Canton of Fribourg 


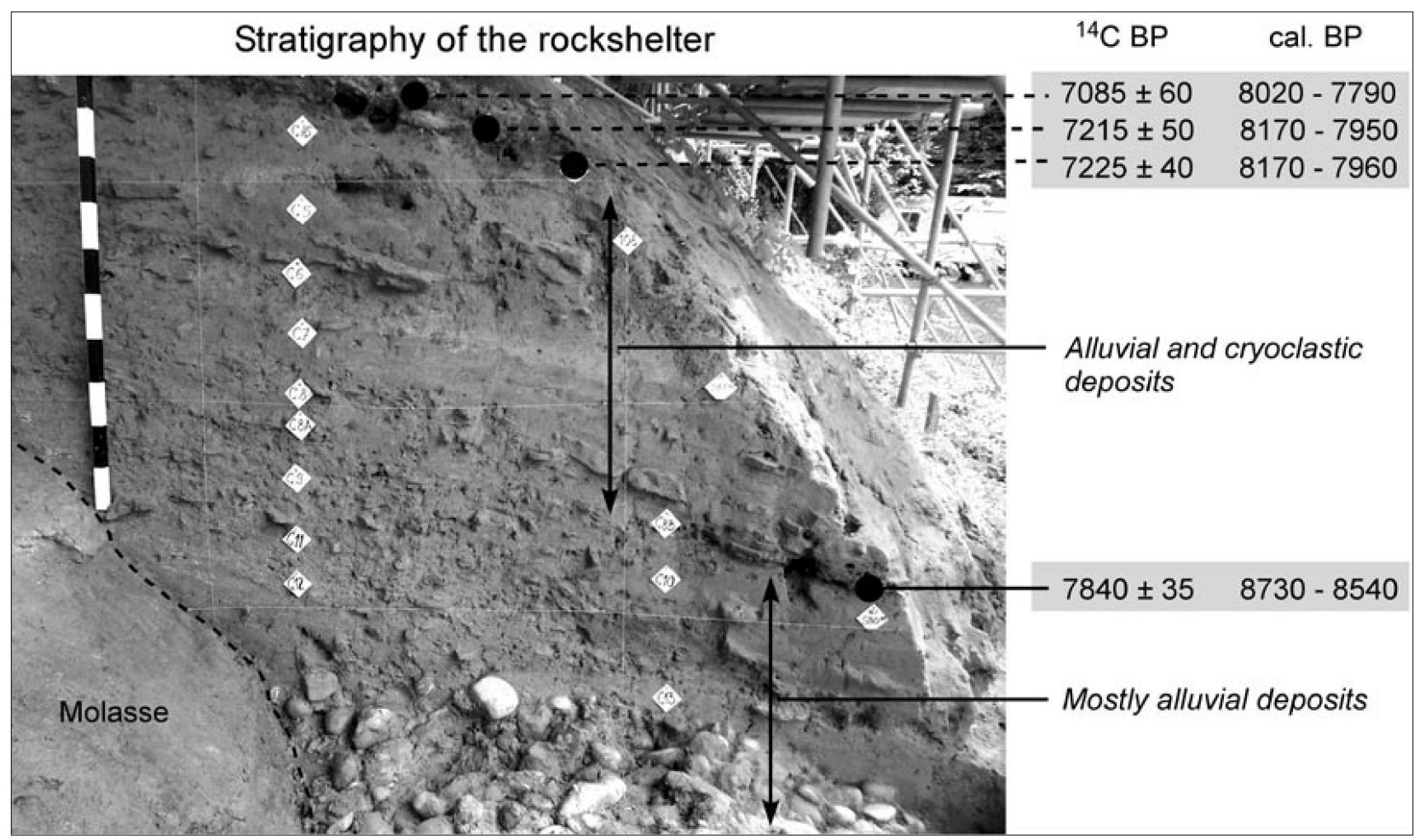

Fig. 7: Base of the infilling of the rockshelter and results of the radiocarbon dating of charcoal and bones found in the archaeological layers

Base du remplissage de l'abri sous roche et résultats des datations radiocarbones réalisées sur des charbons et ossements trouvés dans les couches archéologiques

Auffüllungsbasis des Felsunterstandes und Resultate der Radiokarbondatierungen von Kohle- und Knochenfunden in den archäologischen Schichten

Photo: M. MauviLly

FASEL, G. (2005): Contribution à l'étude de la stratigraphie et des anciens chenaux d'écoulement de la région de Bösingen (Suisse) et création d'une base de données informatisée sur les anciens cours d'eau du canton de Fribourg (Suisse). - = Unpublished master thesis, Institute of Geography, University of Fribourg. Marescot, L., Liaci, S. \& D. Chapellier (2003): Etude géoélectrique des cours d'eau interglaciaires à l'ouest de la ville de Fribourg (Suisse). - In: Eclogae geologicae Helveticae 96, 2: 261-273.

Mauvilly, M., Braillard, L., Dafflon, L. \& J.-L. BoisAUBERT (2004): Arconciel/La Souche, nouveaux éléments pour la connaissance du Mésolithique récent et final. - In: Cahiers d'archéologie fribourgeoise 6: 82-101. Mauvilly, M., Jeunesse, C. \& T. Doppler: Ein frühneolithischer «Tonstempel» in der spätmesolithischen Fundstelle von Arconciel/La Souche (Kanton Freiburg, Schweiz). - In: Quartär (under review).

MEER, J.J.M. vAN DER (1976): Cartographie des sols de la région de Morat (Moyen-Pays suisse). - In: Bulletin de la Société Neuchâteloise de Géographie 54: 5-52.
MEER, J.J.M. VAN DER (1982): The Fribourg area, Switzerland, a study in Quaternary geology and soil development. - = Publicaties van het Fysisch Geografisch en Bodemkundig Laboratorium, University of Amsterdam 32.

Pugin, A. (1989): Déglaciation dans la vallée préalpine de la Sarine en Gruyère:une analyse sédimentologique. - In: Eclogae geologicae Helveticae 82, 1: 285-324.

Weidmann, M., Dorthe, J.-P. \& C. Emmenegger (2002): Feuille 1205 Rossens. - = Atlas géologique suisse 1:25'000, Carte 105.

Weidmann, M. (2005): Feuille 1205 Rossens. - = Atlas géologique suisse 1:25’000, notice explicative 105 .

\section{Abstract: Morphogenesis of the Sarine canyon in the Plateau Molasse, Switzerland: new data from an archaeological site}

The 50 to 100 metre deep canyon of the Sarine River that develops north of the prealpine front in the Molasse Plateau is classically attributed to postglacial erosion. However, the discovery of a Mesolithic 


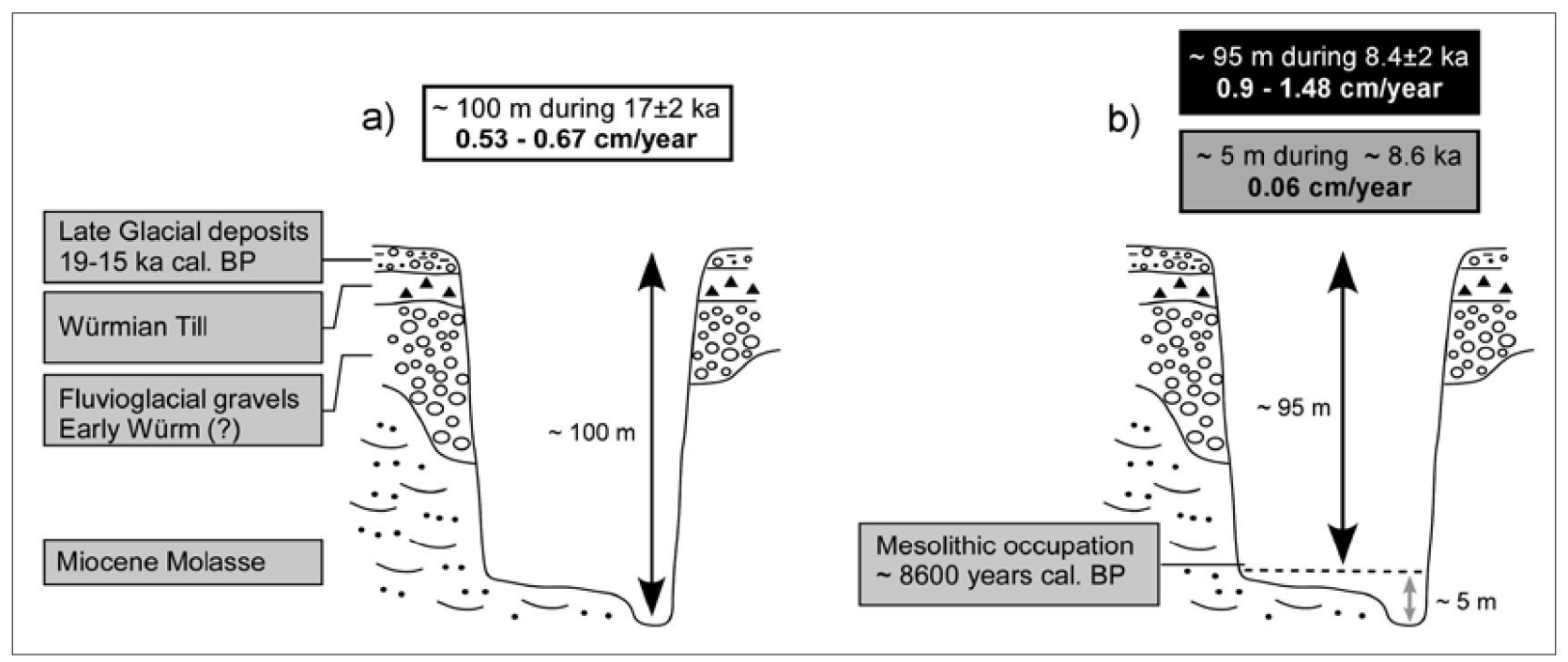

Fig. 8: Erosion rates of the Sarine River since the Late Glacial, assuming that the canyon is a postglacial feature: a) before, and b) after the discovery of the Mesolithic site of Arconciel/La Souche

Taux d'érosion de la Sarine depuis le Tardiglaciaire, en supposant que le canyon est postglaciaire: a) avant et b) après la découverte du site mésolithique d'Arconciel/La Souche

Erosionsrate der Saane seit dem Spätglazial, unter der Annahme der nacheiszeitlichen Entstehung des Canyons: a) vor und b) nach der Entdeckung des mesolithischen Fundplatzes von Arconciel/La Souche

Graphics: L. BRAILLARD

archaeological site ( $~ 8600$ years cal. BP), located at the bottom of the gorge five metres above the actual river bed, has evident implications for the canyon's morphogenesis. This new chronological datum indicates that most of the canyon was already formed 8600 years ago, and that only five metres of Molasse have eroded since that time. This implies a dramatically high erosion rate during Late Glacial to early Holocene times (0.9 to $1.48 \mathrm{~cm} /$ year) and, consequently, a very low erosion rate since the Atlantic period (approximately $0.06 \mathrm{~cm} /$ year). These new archaeological and geological findings offer exciting perspectives for Quaternary research.

Keywords: Sarine canyon, erosion rate, morphogenesis, Mesolithic

\section{Résumé: Morphogenèse du canyon de la Sarine (Molasse du Plateau, Suisse): nouvelles données provenant d'un site archéologique}

Le canyon de la Sarine, qui a incisé la Molasse du Plateau sur une épaisseur de 50 à 100 mètres au nord du front préalpin, est classiquement attribué à l'érosion postglaciaire. La découverte d'un site archéologique mésolithique (environ 8600 années cal. BP), situé au fond des gorges à cinq mètres au dessus du lit actuel de la Sarine a cependant des conséquences évidentes concernant la morphogenèse du canyon. Cette nou- velle donnée chronologique implique en effet que l'essentiel du canyon était déjà creusé il y a 8600 ans et que seuls cinq mètres de Molasse ont été érodés depuis. En conséquence, le taux d'érosion a dû être particulièrement élevé durant le Tardiglaciaire et l'Holocène ancien (entre 0,9 et $1,48 \mathrm{~cm} / \mathrm{an}$ ) et très faible depuis la période Atlantique (environ $0,06 \mathrm{~cm} / \mathrm{an}$ ). La confrontation de ces données archéologiques et géologiques offre des perspectives de recherche réjouissantes.

Mots-clés: Canyon de la Sarine, taux d'érosion, morphogenèse, Mésolithique

\section{Zusammenfassung: Morphogenese des Saane Canyons (Molassebecken, Schweiz): neue Daten einer archäologischen Fundstätte}

Der Saane Canyon, der sich 50 bis 100 Meter in die Mittelland-Molasse im Norden der Voralpen einschneidet, wird klassischerweise mit einer nacheiszeitlichen Erosion begründet. Die Entdeckung einer archäologischen Fundstätte aus dem Mesolithikum ( $~ 8600$ Jahre cal. BP) am Fusse der Schlucht, fünf Meter oberhalb des aktuellen Flusslaufes, hat eine eindeutige Auswirkung auf die Morphogenese der Schlucht. Diese neuen chronologischen Daten zeigen tatsächlich, dass der wesentliche Teil des Canyons bereits vor 8600 Jahren entstanden war, und seitdem nur weitere fünf Meter Molasse erodiert wurden. Folglich muss die Erosions- 
rate während des Spätglazials und Frühen Holozäns aussergewöhnlich hoch (zwischen 0.9 und $1.48 \mathrm{~cm} /$ Jahr) und während der Periode des Atlantikums sehr gering (etwa $0.06 \mathrm{~cm} / \mathrm{Jahr}$ ) gewesen sein. Der Vergleich der archäologischen und geologischen Daten eröffnet neue, spannende Forschungshorizonte.

Schlüsselwörter: Saane Canyon, Erosionsrate, Morphogenese, Mesolithikum

Dr. Luc Braillard, Department of Geosciences/Geology and Paleontology, University of Fribourg, Chemin du Musée 6, CH-1700 Fribourg, Suisse.

e-mail: luc.braillard@unifr.ch

Dipl.-archéol. Michel Mauvilly, Service archéologique du canton de Fribourg, Planche supérieure 13, CH1700 Fribourg, Suisse.

e-mail:mauvillym@fr.ch

Manuskripteingang/received/manuscrit entré le 5.5.2008

Annahme zum Druck/accepted for publication/accepté pour l'impression: 15.9.2008 